\title{
THE ADESSIVE CASE IN POLISH: A COGNITIVE PERSPECTIVE ON SOME LOCATIVE PREPOSITIONS
}

\author{
IWONA KOKORNIAK \\ Adam Mickiewicz University, Poznań, Poland \\ kokorniak@ifa.amu.edu.pl
}

\begin{abstract}
The aim of this paper is to show that what is considered in Polish as one heterogeneous LOCATIVE case in the "formal" approach only on the surface seems rather complex and appears to lack any natural order. Due to the limited size of the paper, focus will be laid only on one locative case, the ADESSIVE, representing the static external locative, expressing different aspects of a relationship outside an entity and describing the "location 'on top of' or 'near', 'owner' or 'instrument' by means of which an action is performed" (Karlsson 1999: 115). It has no single linguistic equivalent in Polish; instead it is represented by several prepositions, such as $n a+\mathrm{LOC}$ 'on', przy + LOC 'by' and $u$ + GEN 'at', etc., reflecting different aspects of proximity and coincidence in space. Taking just the case of the ADESSIVE relation, data observations based on the IPI PAN Corpus of Polish allow us to claim that although each preposition is responsible for a different aspect of the external spatial relation, they complement one another and are related in a family resemblance fashion, expressing an adessive relation.
\end{abstract}

KEYWORDS: Prepositions; adessive; locative; proximity; coincidence.

\section{Introduction}

Over the centuries, the topic of case as a grammatical category has been approached by linguists representing different frameworks. According to Tabakowska (1993: 60), three types of frameworks can be identified. In the continuum, one can find extreme "nonlocalist" theories (e.g. Chomsky 1965), defining cases according to syntactic criteria; extreme "localist" theories, treating case as representing the functions of objects in space (e.g. Kempf 1978; Smith 1987) and, following Cienki (1991), so-called "mixed" theories, which make a distinction between "grammatical", or "logical", cases, such as the NOMINATIVE, ACCUSATIVE and GENITIVE, being given a purely syntactic interpretation, and cases spatial in meaning, such as the LOCATIVE or INSTRUMEN- 
TAL, representing more spatial relations and functions. This distinction finds confirmation in Brecht and Levine's (1986: 21) comment on the theories of case:

\begin{abstract}
one can speak of two extremes in the assessment of the semantic load of case forms: On the one view, case morphemes contribute meaning on their own, meaning which is obligatorily in agreement with the other lexical and grammatical meaning of the utterance. The other view is that morphological case is dictated by the structure of the sentence itself or by the governing caseassigning verb or preposition. On this latter view, case forms are basically meaningless.
\end{abstract}

According to the extreme localist theory, which has gained credence in the Finnish case system, the "very essence of case are the functions of objects in space" (Kempf 1978: 6, as quoted in Tabakowska 1993: 60). As presented in Finnish, six cases form a subsystem of their own, organised according to two dimensions: one is location, including (a) "internal" and (b) "external" positions; the other is direction, with (1) "static", (2) "movement away from" and (3) "movement towards" (Karlsson 1999: 107). They can be grouped accordingly:

Table 1. Locative cases in Finnish.

\begin{tabular}{llccc}
\hline & & 1 & 2 & 3 \\
\hline (a) & INTERNAL & inessive & elative & illative \\
(b) & EXTERNAL & adessive & ablative & allative \\
\hline
\end{tabular}

As Table 1 shows, in the system of locative cases one can identify "external locatives" and "internal locatives". Whereas the former represent aspects of a relationship outside something, the latter refer primarily to relationships depending on position within an object (Atkinson 1977: 30-33). To illustrate only the static internal and external locatives, i.e. the inessive and adessive, Leino's (1990: 129-130) examples are used:

(1a) Pullossa on vettä

bottle-INE is water-PARTITIVE

'There's water in the bottle.'

(1b) Pullossa on etiketti.

bottle-INE is label

'There's a label on the bottle./The bottle has a label.'

(2a) Joku on ovella.

someone is door-ADE

'There's someone at the door.' 
(2b) Lamppu on pöydällä.
lamp is table-ADE
'The lamp is on the table.'

The examples in (1) conceptualise the relations of "inclusion" and "contact", respectively, with the second relation understood as an elaboration of the first one since the label is in contact with the bottle at the same time being considered as its part. In (2), on the other hand, the first relation is referred to as "association" with a dimensionally unspecified point as the LM, and the second relation as a "surface" implying contact of the Trajector (henceforth TR) ${ }^{1}$ with the top of the Landmark (LM).

The purpose of this paper is to analyse just one of the locative cases, the ADESSIVE, representing the static external locative (highlighted in Table 1), describing the "location 'on top of' or 'near', 'owner' or 'instrument' by means of which an action is performed" (Karlsson 1999: 115), in order to show that its case inflection is coherently regarded as meaningful in Polish.

As Kempf (1978: 110) observes, no instance of the ADESSIVE case has ever occurred without a preposition in Polish. ${ }^{2}$ ADESSIVE constructions would employ a preposition followed by a noun in the LOCATIVE (LOC) or GENETIVE (GEN) case.

\footnotetext{
${ }^{1}$ The trajector (TR) and the landmark (LM) are relative in the sense that they are always described as a relation with regard to each other. Langacker $(1987: 217)$ defines the TR as the figure within the relational profile. The LM, in turn, he describes as "providing a point of reference for locating the trajector". Both the TR and LM are located within the so-called "dominion", i.e. "the conceptual region (or the set of entities) to which a particular reference point affords direct access" (Langacker 1993: 6).

Each relation of the TR and LM is asymmetric in some way. The TR is usually smaller than the LM, mobile, and in the focus of attention - in the foreground. The LM as an entity with respect to which the position of the TR is defined, is usually larger, cognitively familiar, and less mobile than the TR; its position is known to both the speaker and the listener. The TR and LM may be of equal size, but the TR is hardly ever bigger or less mobile than the LM.

Another parameter that should be considered is the dimensionality of the TR and LM. Both can be three-dimensional, like a house, table, or car; two-dimensional, like a floor, roof, or a sheet of paper; or onedimensional, like a line. However, dimensionality should not be treated as a criterion of primary importance, since the same three-dimensional object may be perceived either as a volume or surface. For example, we may ignore a door's thickness and treat it as a two-dimensional surface, and hence say Someone is knocking on the door. We may, however, take into consideration the third dimension when we say There is a hole in the door.

${ }^{2}$ In Polish, the ADESSIVE is represented not only by the case marking but also by prepositions, and thus it belongs to the analytical cases. Synthetic cases, on the other hand, are reflected just by case endings. Blake (1994: 9) provides Latin as a language belonging to the former type, and Japanese as a representative of the latter, possessing only postpositions as case markers. Since both case endings and pre/postpositions represent cases, it seems logical that one can "ignore any distinction that might be drawn between 'case' and 'pre/postposition' [...], and include under the label 'case' [...] 'functional' elements in general (while not neglecting the fact that prepositions, for instance, appear to be more appropriate to the representation of certain functions than others)" Anderson (1977: 5). In fact, Janda (1993: 23) notes that the line between prepositional and "prepositionless case is indistinct and crossable".
} 
Only several representatives of the case $-n a+\mathrm{LOC}$, przy $+\mathrm{LOC}$, and $u+\mathrm{GEN}^{3}-$ are brought into focus here. In majority, the Polish examples discussed in this paper come from the IPI PAN Corpus. ${ }^{4}$

\section{The ADESSIVE in Polish}

The adessive is closely linked to proximity and profiles a number of external relations between the TR and LM, which in Polish have no single linguistic equivalent; instead, it is represented by several prepositions, such as $n a+$ LOC, przy + LOC and $u+$ GEN among others, complementing one another and reflecting different aspects of proximity and coincidence. Case endings for the adessive include $-u,-(i) e,-y,-i$ or $-a$, depending on the gender of the LM. These locative prepositions and case-endings used spatially represent C-predicates, ${ }^{5}$ whose base is physical space.

If we were to distinguish the types of contact that the adessive case represents, we would notice that $u+$ GEN represents the smallest degree of contact, conceptualised as a point, as in (3a), przy + LOC typically conceptualises linear contact or a lateral relation with no contact at all, as in (3b), whereas $n a+$ LOC conceptualises contact between two surfaces, where the LM supports a TR from falling down with the force of gravity exerting influence on the LM, as in (3c):

$\begin{array}{lllll}\text { kot } & \mathrm{z} & \text { dzwonkiem } & \mathrm{u} & \text { szyi } \\ \text { cat } & \text { with } & \text { bell } & \text { at } & \text { neck-GEN }\end{array}$
'a cat with a bell around his neck'

gmerający przy szyi $\quad$ w poszukiwaniu
looking by neck-LOC in search-LOC
'searching for a tie around his neck'
miał na szyi $\quad$ krawat
(he) had on neck-GEN tie-ACC
'he had a tie round his neck'

\footnotetext{
${ }^{3}$ The analyzed prepositions will either appear in italics $-p r z y+\mathrm{LOC}-$ to represent their form, or in capitals put in square brackets $-[$ PRZY + LOC $]-$ to stand for their predicate.

${ }^{4}$ The corpus is located at $<\mathrm{http}: / /$ korpus.pl $>$. It is a large corpus - in a newer 2 nd version containing about 250 million segments - which is morphosyntactically annotated. It has been developed at the Institute of Computer Science at the Polish Academy of Sciences (cf. Przepiórkowski 2006). For the purposes of this study, the IPI PAN Corpus Sample has been used, containing over 30 million segments.

${ }^{5}$ In a symbolic structure that Langacker (1987: 97) considers as the basic unit of Cognitive Grammar, with the distinction of a semantic and a phonological pole therein, the semantic structure of any linguistic expression is referred to as predication, whereas a minimal semantic structure of a morpheme is referred to as a predicate. The predicate profiles an entity in relation to a base; the base is the ground and the predicate picks out an entity by highlighting it or bringing it into focus. Case-endings and prepositions represent what is referred to here as case predicates (C-predicates), i.e. predicates that profile stative or atemporal relations.
} 
Thus, when it comes to the reflection of the ADESSIVE relation, each preposition is responsible for a different aspect of the spatial relation.

Apart from the typical conceptualisations presented above (Przybylska 2002), each preposition may represent a number of other spatial relations. ${ }^{6}$ As will be shown below, although the spatial relations indicated by the prepositions may seem so different, they have one feature in common: they conceptualise proximous relations, all involving the adessive feature.

\section{1. $N a+\mathrm{LOC}$}

To start with, the predicate of $n a+$ LOC may indicate general location, where the LM, which is conceptualised as a point and whose dimensions, size and shape are ignored, coincides with the TR. The coincidence of the two entities may involve the TR's location within the LM's dominion. Important is the fact that we can localise the TR with regard to the LM. Thus, $n a+\mathrm{LOC}$ indicates the general location of the TR with regard to the LM (Sysak-Borońska 1980: 70; Cienki 1989: 110-111). This sense of $n a$ does not necessarily imply contact between the TR and LM, a characteristic feature of the preposition, but rather forms some association between the two entities. Consider the following sentences:

$\begin{array}{lllll}\text { Jan Paweł II } & \text { na lotnisku } & \text { w } & \text { Balicach } \\ \text { John Paul II } & \text { on } \begin{array}{l}\text { airport-LOC } \\ \text { in }\end{array} & \text { Balice } \\ \text { 'John Paul II at the airport in Balice.' } & & \end{array}$

In the above sentence, we do not know where precisely the TR is located; what is known is only its approximate location with regard to the LM as the point of reference.

Klebanowska (1971: 20-21) observes this type of occurrence of $n a+$ LOC when discussing the differences between expressions such as na zamku 'at the castle' and $w$ zamku 'in the castle', or na mieście 'at the city' and $w$ mieście 'in the city'. Whereas $w$ + LOC implies the existence of boundaries imposed on the LM, the instances with $n a$ do not provide any specific indication of location; they only indicate the whereabouts of the TR.

This regularity of occurrence of $n a+$ LOC is confirmed by Sysak-Borońska (1980: 64), who enumerates some further instances, noting, however, that they are employed in restricted contexts. Consider:

(5a) Kasia jest na basenie.

Kate is on swimming pool-LOC]

'Kate is at the swimming pool.'

\footnotetext{
${ }^{6}$ The list of the senses analysed here is not exhaustive. The author only aims to show how the senses are related to one another.
} 
'Kate is in the swimming pool.'

Sentence (5a) does not conceptualise the TR inside the LM. The TR could just as well go to the swimming pool, the LM, but not actually be in the pool. Sentence (5b), on the other hand, implies the conceptualisation of the LM as a container and locates the TR more precisely with regard to the LM, that is, within its confines.

The tendency to indicate general location by means of $n a+$ LOC, as SysakBorońska (1980: 70) notes, has grown since the 1960s in colloquial Polish, particularly with reference to the place of work. In such occurrences it is reference to buildings and institutions that is made. Consider:

$$
\begin{aligned}
& \text { Ona uczy na uniwersytecie w Massachusetts. } \\
& \text { She teaches on university-LOC in Massachusetts-LOC } \\
& \text { 'She teaches at the University of Massachusetts.' }
\end{aligned}
$$

$\mathrm{Na}+$ LOC does not indicate a functional aspect of the place here. If it were present, as maintained by Awdiejew (1977: 107), the verb być 'to be', instead of $u c z y c$ ' to teach', should also bring some associations with an activity undertaken in the location. However, the sentence then becomes rather ambiguous:

$$
\begin{aligned}
& \text { Ona jest na uniwersytecie w Massachusetts. } \\
& \text { She is on university-LOC in Massachusetts } \\
& \text { 'She is at the University of Massachusetts.' }
\end{aligned}
$$

Unless some context is provided, (7) specifies the location of the place of study for the TR rather than work. The use of $n a+$ LOC to indicate general location is restricted. Clear rules of its occurrence, though, are hard to formulate.

The predicate of $n a+$ LOC can be extended from the spatial relation of a general location to apply to activities, ${ }^{8}$ indicating not only the place but also the time of their occurrence. In example (8), via the ACTIVITIES ARE LOCATIONS metaphor (see

\footnotetext{
${ }^{7}$ Wielki Stownik Poprawnej Polszczyzny (WSPP) indicates that Polish linguists have not accepted the use of $n a+\mathrm{LOC}$ unanimously in all contexts, showing that $w+\mathrm{LOC}$ is still officially accepted in pracowac $w$ uniwersytecie 'to work in the university', although the form pracowac na uniwersytecie 'to work at the university' is also acceptable. It should be noted, however, that studiować/wykladać na uniwersytecie 'to study/ lecture at the university' is correct, and $w+\mathrm{LOC}$ in *studiować/wykładać w uniwersytecie 'to study/lecture in the university' is not.

${ }^{8}$ The boundary between activities and events, the latter being composed of activities, actions, locations etc., seems to be vague in some cases. Dinner and mass can be considered either as activities or events depending on their complexity and location. Here, they are treated not as complex events, but as the activities of having a meal and saying fixed forms of words to God, respectively.
} 
Kokorniak 2007: 83), the activity of participating in a concert is construed as not a highly specific location:

(8) Miał zrobić fotografie na koncercie Kristiana Zimermana.

(He) had do-INF. photos on concert-LOC K.-GEN Z.-GEN

'He was to take photos at Kristian Zimerman's concert.'

$\mathrm{Na}+\mathrm{LOC}$ is also appropriate in a number of topographical and geographical locations; it is used when the LMs are construed as devoid of clear boundaries, e.g.:

(9) Nikt nic nie robił na placu budowy.

No one nothing not did on construction-LOC site-GEN

'Nothing has been done at the construction site.'

For $n a+$ LOC to be used, the geographical locations ought to be conceptualised not as the central but as a peripheral part of a larger area, e.g. a suburb of a city. ${ }^{9}$

Finally, $n a+$ LOC is used in some part-whole relations, precisely when the TR is related to a part of the LM. An extreme part of the LM is the location of the TR, as in (10):

(10a) $\mathrm{Na}$ końcu ulicy pojawiła się męska sylwetka. On end-LOC street-GEN appeared REFL. male silhouette 'A male silhouette appeared at the end of the street.'

(10b) Inżynier zjawił się na szczycie góry. Engineer appeared REFL. on top-LOC mountain-GEN 'An engineer appeared at the top of a mountain.'

Thus, in the predicate of $n \mathrm{a}+\mathrm{LOC}$ one can observe a transition from a typically contiguous relation (as in (3c)) to coincidence (example (4)), and to a part-whole relation (examples (10a-b)), where the genitive is used to indicate the whole.

The part-whole relation can be extended metaphorically to indicate one's hierarchical position at work, as in:

(11) Margaret spodziewała się pracy na stanowisku archeologa Margaret expected REFL. job-GEN on post-LOC archeologist-GEN 'Margaret expected to get a job as an archeologist.'

\footnotetext{
${ }^{9}$ Whereas the names of cities always appear with $w+$ LOC, city districts can occur either with $w+$ LOC or $n a+$ LOC. Przybylska (2002: 224-225) observes that suburban districts are used with $n a+$ LOC, e.g. $n a$ Winogradach 'on Winogrady', na Piatkowie 'on Piątkowo', and central ones collocate with $w+$ LOC: $w$ Śródmieściu 'in Śródmieście'.
} 
To a certain extent, the part-whole relation of $n a+\mathrm{LOC}$ is shared with $u+\mathrm{GEN}$, where the genitive case is used for both the part and whole, e.g.:
Usiedli
na/u skraju
lasu,
obok siebie.
(They) sat on/at edge-LOC/GEN wood-GEN, beside them-REFL
'They sat at the edge of the woods, next to each other.'

The overlap of $n a$ and $u$ can be explained by the fact that items that are parts of physical objects can also be understood as being located on the larger entities that they belong to (Janda 2004). Whereas $u+$ GEN focuses more on possession, $n a+$ LOC indicates a location of the entity that it belongs to.

Sometimes $n a+$ LOC represents external proximity, and then it often alternates with przy + LOC. The TR bears a lateral relation to the LM, but the position is not precise, and it may be considered as coincident or rather contiguous with the LM, contiguity being usually reflected by means of $n a+$ LOC in Polish: ${ }^{10}$
(13) kościół na/przy rogu
ulic
Ludźmierskiej
i Obrońców
Krzyża
church on/by corner-GEN streets-GEN Ludźmierska-GEN and Obrońcy
Krzyża-GEN
'the church at the corner of Ludźmierska and Obrońców Krzyża Street'

Example (13) shows that substitution of przy for $n a$ is possible, conceptualising a slightly different spatial relation, both involving an adessive feature though.

\subsection{Przy $+\mathrm{LOC}$}

Another Polish preposition, przy + LOC, conceptualises an external location where a TR is situated in proximity to a three-dimensional LM and direct contact is possible. The TR can be situated very close to the front, back, ${ }^{11}$ or one of the sides of the LM. What is more, in the majority of instances the function of the LM is implied, as in (14a-e), or has

\footnotetext{
${ }^{10}$ Cienki (1987: 4) observes a somewhat different correspondence between $n a+$ LOC and przy + LOC in Polish. He remarks that the exterior relation of $n a+\mathrm{LOC}$ is different from that of przy $+\mathrm{LOC}$, since the latter is apprehended as expressing the TR being merely an addition to the LM, not a constituent part, whereas the former expresses contact which is either direct or intermediary with the LM.

${ }^{11}$ The front or back relation towards the LM can also be expressed in Polish by przed 'in front of' and $z a$ 'behind', respectively. Klebanowska (1969: 184-187) indicates that both prepositions may convey an inherent or a relative relation between the object localised [here: TR] and the localiser [LM]. In the inherent relation the LM possesses an inherent front and the TR is oriented towards it. LMs with an inherent front, and hence back, include entities such as cars, computers, wardrobes, houses, etc.; their front is the part which is exposed to an observer and which may be functionally salient.
} 
some connection or association when the two entities are inanimate, as in (14f). Consider the following examples:
(14a) Marek siedzi przy komputerze.
Mark sits/is sitting by computer-LOC
'Mark is sitting at the computer.'
(14b) Ukklękłam przy ołtarzu.
(I) knelt by altar-LOC
'I knelt at the altar.'
(14c) Paulina siedzi przy stole.
Pauline sits/is sitting by table-LOC
'Pauline is sitting at the table.'

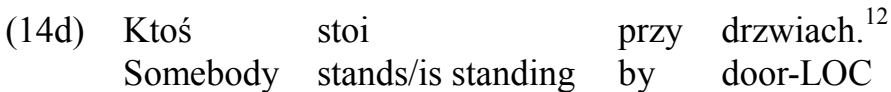
'Somebody is standing at the door.'
(14e) Zosia stoi przy oknie. ${ }^{13}$
Sophie is standing by window-LOC
'Sophie is standing at the window.'
(14f) krzesło przy stole chair-NOM by table-LOC
'a chair at the table'

In (14), each C-predicate involves a TR oriented in very close proximity to the LM. As indicated by Klebanowska (1969: 185), the TR is oriented towards the functional side of the LM, and hence is capable of using it. However, no function needs to be present for the relation to be rendered by means of przy, as in (15):

\footnotetext{
${ }^{12}$ Examples (14a-b) can also be expressed by means of przed: Marek siedzi przed komputerem, Uklęktam przed ottarzem. In (14c-d), on the other hand, przy could be replaced with za: Paulina siedzi za stotem, Ktos stoi za drzwiami. Whereas the former sentences involve the LM with an inherent front, the latter depend on the viewpoint of the observer. If they incorporated the przed-relation, e.g., przed stotem 'in front of the table' or przed drzwiami 'in front of the door', which is plausible but highly infrequent, their implications would be different. The functional aspect, which is often employed in such relations, would no longer then be present.

One explanation that may be offered in favour of $z a$ in the relative relation is its prototypicality: "[p]rototypically, this arrangement involves a spatial orientation relative to the observer, i.e. it implies a spatial configuration with a 'proximal' entity (the landmark) and a 'distal' entity (the trajector), as established from the vantage point of the speaker [...]. As this particular arrangement is the simplest conceptually, it is unanimously listed in dictionaries as the first, i.e. the main use of $z a$ " (Tabakowska 2003: 161-162).

${ }^{13}$ In this sentence, the relation between the LM, the window, and the TR, Zosia, can be interpreted in a twofold way. First, it can be construed as a lateral relation, where the TR is oriented next to the LM. Second, the LM can be conceptualised as a flat container within whose frame the TR can be included, and thus can be reflected lexically as Zosia stoi w oknie 'Sophie is standing in the window'.
} 


\begin{tabular}{|c|c|c|c|}
\hline $\begin{array}{l}\text { Mężczyzna } \\
\text { man }\end{array}$ & $\begin{array}{l}\text { przy } \\
\text { by }\end{array}$ & $\begin{array}{l}\text { samochodzie } \\
\text { car-LOC }\end{array}$ & $\begin{array}{l}\text { zobaczył } \\
\text { saw }\end{array}$ \\
\hline
\end{tabular}

'The man by the car saw someone.'

The lateral relation conceptualizing a position 'near' or 'next to' can be extended to apply to sensory phenomena which accompany the TR both in space and time, as in (16):
Zdjął
czapkę, zdjął futro
i usiadł przy świecy.

(He) off-took hat-ACC, off-took fur coat-ACC and sat by candle-LOC

'He took off his hat, fur coat and sat by candlelight.'

The predicate of przy + LOC can also be extended to indicate the use of an instrument as a helping tool to perform an activity:

(17) Złodzieje przy pomocy klucza dostali się przez tylne wejście Thieves by help-LOCkey-GENgot REFL.through back entrance-ACC 'Thieves got in through the back door with the help of a key.'

In restricted context, the przy predicate can be extended from the "lateral position" to 'possession', which can be exemplified as follows:

(18a) Po przerwie nadal przy piłce byli Japończycy, After break still by ball-LOC were Japanese 'After the break the Japanese team still had the ball.'

(18b) Skoro AWS jest przy władzy, efekty powinny już być since AWS is by power-LOC effects should already be 'Since AWS is in power, its effects should already be visible.'

Whereas (18a) conceptualises the LM as a physical entity which the TR possesses, example (18b) portrays power as an abstract entity that is possessed.

According to Przybylska (2002: 496-497), the LM can also be idealised as a point in the przy + LOC predicate in space. All geometrical features of the LM are irrelevant - only the closeness of the TR to the LM, or their contact, is at issue. Consider the following examples:

(19a) Spotkaliśmy się przy pomniku. $^{14}$

(We) met REFL. by monument-LOC

'We met at the monument.'

\footnotetext{
${ }^{14}$ The relation between the TR and LM in example (20a) can also be expressed with pod + INSTR: Spotkaliśmy się pod pomnikiem [(We) met under the monument-INSTR] 'We met at the monument'. In that case, the lesser height of the TR is rendered in relation to the LM, as well as the feature of "proximity" which is "considered here as a subjective estimation made by the speaker" (Cienki 1987: 5).
} 
(19b) Dziewczyna stała przy studni.

Girl stood by well-LOC

'A girl was standing at the well.'

However, the extent to which the TR is used as coinciding with a one-dimensional point as a LM with przy + LOC is not so common. Coincidence has also been discussed for $n a+\mathrm{LOC}$ (cf. example (4)). However, this type of relation conceptualises an internal type of coincidence. Przy + LOC, on the other hand, conceptualizes an external type.

\section{3. $U+\mathrm{GEN}$}

The next preposition, $u+$ GEN, may conceptualise either an external or internal spatial relation; the latter one is more frequent, though. As indicated by Lesz-Duk (1991: 374) in her diachronic approach, the most frequent schema of $u+$ GEN, instances of which are provided in (20), may indicate either the owner of the place or its user, where the name of a person collocating with the English preposition metonymically stands for the place they own or live in. ${ }^{15}$ In examples $(20 \mathrm{a}-\mathrm{b})$, the location primarily constitutes a point of reference to orientate the TR in space, which is indicated by the genitive form of the noun in the LM position.

(20a) Jestem u (mojej) babci.

(I) am at (my) granda-GEN

'I'm at my grandma's.'

(20b) Spotkajmy się u Tomka.

Meet-let's REFL. at Tom-GEN

'Let's meet at Tom's.'

The person may also stand metonymically for the place where they provide some service related to their occupation. The function of the place is usually implied, as in instances $(21 \mathrm{a}-\mathrm{b})$ :

(21a) Maria jest u rzeźnika.

Maria is at butcher-GEN

'Marie is at the butcher's.'

(21b) Paweł jest u dentysty.

Paul is at dentist-GEN]

'Paul is at the dentist's.'

\footnotetext{
${ }^{15}$ Langacker (1993) however, argues that what he calls the pronominal possessive constructions have little to do with location; rather the possessor nominal designates a "reference point entity", which provides conceptual access to the possessee/possessor.
} 
Sentence (21a) indicates the reason why the TR, Maria, is at the butcher's; namely, she wants to buy some meat. Similarly, in (21b) the visit at the dentist's suggests that the TR, Pawet, is going to have his teeth attended to. It is worth mentioning that the person indicated in the genitive case does not have to be the one who provides the service as long as it is provided professionally. Instead of the butcher or the dentist, it can be their assistants who sell meat and look after teeth, respectively.

As Topolińska (1984: 282-284) notes, there are a number of instances where $u+$ GEN collocates with the name of a person, which implies the service that person provides but not the location. Consider (22):

$$
\begin{aligned}
& \text { Uczę się angielskiego u profesor Kowalskiej. }{ }^{16} \\
& \text { (I) study REFL. English-GEN at professor-Kowalska-GEN } \\
& \text { 'I study English with professor Kowalska.' }
\end{aligned}
$$

In the above example, profesor Kowalska is the person who provides the service. Nevertheless, no implication of the LM of the service is made. Thus, the sentence can be interpreted as 'Professor Kowalska teaches me English' rather than 'Professor Kowalska's place is where I am taught English', which supports Langacker's (1993) claim regarding reference point constructions.

The service provider does not even have to be a professional for $u+$ GEN to be applicable in Polish, as in:

$$
\text { Czeszę się u pani Smith. }
$$

(I) comb REFL. at Mrs-GEN Smith

'I have my hair done by Mrs Smith.'

Thus, it is not the location but the agent which is indicated in the $u+$ GEN predicate in the two examples.

Another less frequent occurrence of $u+$ GEN refers to the extreme part of the LM. In the majority of cases the part-whole relation of the LM is involved, where the contact between the TR and LM is apprehended as involving merely a point. Thus, the most prominent part of the LM is the location of the TR. Contact between the TR and LM is a possible but not a necessary element of the configuration. Consider:

(24a) Odkryła, że historia choroby u wezgłowia (She) out-found that history-NOM illness-GEN at head-LOC lóżka dotyczyła innego pacjenta. bed-GEN referred another-GEN patient-GEN

'She found that the medical chart kept at the head of the bed related to some other patient.'

\footnotetext{
${ }^{16}$ Example (22) has been adapted from Topolińska (1984: 279).
} 
(24b) Urodzili się u podnóża Tatr. they bore REFL. at foot-GEN Tatras-GEN 'They were born at the foot of the Tatras.'

In example (24a), the TR is contiguous with the LM along its edge, which still can be regarded as its extreme part. In (24b) the type of contact is unclear due to the fuzzy boundary of the mountain foot. Regardless of the degree of contact in the real world, it can be assumed that little contact is involved.

A number of instances of $u+$ GEN, such as $u d r z w i$ 'at the door', $u$ bramy 'at the gate', constitute stylistically marked individual instances of this occurrence which is also possible with przy + LOC: przy drzwiach 'by the door' or przy bramie 'by the gate'.

The part-whole relation represented by $u+$ GEN can also be extended metaphorically, as is the case in example (25):

(25a) Jezus wiedział, co Go czeka u kresu Jego ziemskiego życia. Jesus knew what him waits at end-GEN his earthly-GEN life-GEN 'Jesus knew what awaited him at the end of his earthly life.'

(25b) Będący u kresu wytrzymałości mężczyzna

being at end-GEN endurance-GEN man

postanowił szukać ratunku na policji.

decided seek-INF. help-GEN on police

'Driven to the limits of endurance, the man decided to seek help from the police.'

Whereas in (25a) the $u$ predicate is used in the temporal domain to indicate an extreme point of the timeline, in (25b) $u+$ GEN is applied in the state domain.

\section{Conclusions}

Together, the prepositions $n a+\mathrm{LOC}$, przy $+\mathrm{LOC}$ and $u+$ GEN reflect a case predicate [ADESSIVE]. The LM of the predicate [ADESSIVE] can be a dimensionally unspecified point, as in $u+$ GEN, where the relation between the TR and LM can be called "association". Another type of relation that the adessive represents involves the LM idealized as a two-dimensional surface. This type of relation can be described either as "contact", as for $n a+\mathrm{LOC}$, where a TR is located on top of the LM, or as lateral relation, as for przy + LOC, where the TR is oriented laterally with regard to the LM. In all the cases, when the LM is perceived as a point, as a surface, or in lateral position, it must have a sufficiently extensive and salient dominion.

Although the Polish markers of the ADESSIVE presented above constitute just a sample of schemas representing the adessive case, one could observe that the schemas 
are connected with one another in a systematic way. $\mathrm{Na}+\mathrm{LOC}$ reflects the spatial relation of the TR located "on top of", or "coincident" with the LM. Metaphorically, it can also conceptualise a social position one holds in a hierarchical structure. When it conveys a part-whole relation, in certain contexts it may overlap, and be replaced, with $u+$ GEN or przy + LOC. When the former is used, focus is laid on the part (TR) belonging to the whole (LM), rather than the TR being located within the dominion of the LM. The primary function of przy + LOC is to construe a spatial relation of a TR located "near" a LM. However, its predicate may be extended to render an accompanying activity or an instrument used to perform an action. In restricted context, przy + LOC may also conceptualise possession (example 19), a feature characteristic of $u+$ GEN.

Conceptualising different aspects of proximity, coincidence, possession and instrumentality, the predicates of $n a+$ LOC, $u+$ GEN and przy + LOC complement one another in the reflection of the adessive relation. The fact that the predicates overlap peripherally constitutes yet another indicator that they share the adessive feature.

\section{REFERENCES}

Anderson, J.M. 1977. On case grammar: Prolegomena to a theory of grammatical relations. London: Croom Helm.

Atkinson, J.J. 1977. A Finnish grammar. Helsinki: Finnish Literature Society.

Awdiejew, A. 1977. "Konkurencja przyimków w/na w języku polskim i rosyjskim" [Competition between the prepositions w/na in Polish and Russian]. Poradnik Językowy 3. 106-110.

Blake, B.J. 1994. Case. Cambridge: Cambridge University Press.

Brecht, R.D. and J.S. Levine. 1986. "Case and meaning”. In: Brecht, R.D. and J.S. Levine (eds.), Case in Slavic. Columbus, OH: Slavica. 17-34.

Chomsky, N. 1965. Aspects of the theory of syntax. Cambridge: MIT Press.

Cienki, A. 1987. "Selected Polish spatial prepositions and their Russian counterparts in form and meaning". Canadian Slavonic Papers 19. 1-23.

Cienki, A. 1989. Spatial cognition and the semantics of prepositions in English, Polish, and Russian. Munich: Sagner.

Cienki, A. 1991. "Echoes of localist theories of case in cognitive linguistics". Paper presented at the ICLA Conference, Santa Cruz.

Cuyckens, H., T. Berg, R. Dirven and K.-U. Panther (eds.). 2003. Motivation in language. Amsterdam: John Benjamins.

Janda, L. 1993. A geography of case semantics: The Czech dative and the Russian instrumental. Berlin: Mouton de Gruyter.

Janda, L. 2004. "Border zones in the Russian case system". In: Apresjan, J.D. (ed.), Sokrovennye smysly. (A festschrift for Nina D. Arutjunova). Moscow: Jazyki slavjanskoj kul'tury. 378398.

Karlsson, F. 1999. Finnish: An essential grammar. (Translated by Andrew Chesterman.) London: Routledge.

Kempf, Z. 1978. Próba teorii przypadków [An essay on case theory]. Opole: Zakład Narodowy im. Ossolińskich.

Klebanowska, B. 1969. "Funkcja przyimka przez i za" [Function of the prepositions przed and za]. Język Polski 49. 183-192. 
Klebanowska, B. 1971. Znaczenia lokatywne polskich przyimków właściwych [The locative meaning of Polish prepositions proper]. Wrocław: Ossolineum.

Kokorniak, I. 2007. English at: An integrated semantic analysis. Frankfurt am Main: Peter Lang. Langacker, R.W. 1987. Foundations of cognitive grammar. (Vol. 1: Theoretical prerequisites.) Stanford: Stanford University Press.

Langacker, R.W. 1993. "Reference-point constructions". Cognitive Linguistics 4. 1-38.

Leino, P. 1990. "Spatial relations in Finnish in a cognitive perspective". In: Almquist, I., P.-E. Cederholm and J. Lainio, Från pohjolas pörten till kognitiv kontakt. Stockholm: Stockholm University Press. 117-152.

Lesz-Duk, M. 1991. "Konstrukcje z przyimkiem $u$ w polszczyźnie" [Constructions with the preposition $u$ in Polish]. Poradnik Jęzkowy 9-10. 122-209.

Markowski, A. (ed.). 2004. Wielki stownik poprawnej polszczyzny (WSPP) [The great dictionary of correct Polish]. Warszawa: Wydawnictwo Naukowe PWN.

Przepiórkowski, A. 2006. "The potential of the IPI PAN Corpus". Poznań Studies in Contemporary Linguistics $41.31-48$.

Przybylska, R. 2002. Polisemia przyimków polskich w świetle semantyki kognitywnej [Polysemy of Polish prepositions within the framework of cognitive semantics]. Kraków: Universitas.

Smith, M. B. 1987. The semantics of dative and accusative in German: An investigation in Cognitive Grammar. (Unpublished PhD dissertation, University of California, San Diego.)

Sysak-Borońska, M. 1980. The spatial system in Polish and English: Prepositions of direct location. (Unpublished PhD dissertation, University of Silesia, Katowice.)

Tabakowska, E. 1993. "A case for a case: Finnish Elative from a cognitive perspective”. In: Górska, E. (ed.), Images from the cognitive scene. Kraków: Universitas. 59-72.

Tabakowska, E. 2003. "Space and time in Polish: The preposition $z a$ and the verbal prefix $z a-$-". In: Cuyckens, H., T. Berg, R. Dirven and K.-U. Panther (eds.), Motivation in language. Amsterdam: John Benjamins. 153-177.

Topolińska, Z. 1984. "O konstrukcjach typu Czeszę się u pana Zenona" [About constructions of the type 'I have my hair done at X's'], Acta Baltico-Slavica 16. 279-285.

\author{
Address correspondence to: \\ Iwona Kokorniak \\ School of English \\ Adam Mickiewicz University \\ Al. Niepodległości 4 \\ 61-874 Poznań \\ Poland \\ kokorniak@ifa.amu.edu.pl
}

